\title{
Evaluating Determinants of Organizational Commitment: A Comparative Analysis of Public and Private Sectors
}

\author{
Kamran Ahmed Malik \\ Dr. Manzoor A. Khalidi
}

\begin{abstract}
This study was conducted to evaluate the determinants of organizational commitment in public and private sectors organizations of Pakistan. Organizational commitment is a behavior that extends beyond the functions and conduct formally required of workers in an organization. Such behavior is indispensable because of its contribution to better organizational performance. In order to adapt to environment constraints, the executives now a days try to promote certain behaviors and aspects among employees that ultimately stimulates the commitment towards organization. Hence to function successfully, each organization is interested in exploiting factors that determine the organizational commitment of the employee. Although there have been numerous international studies on organizational commitment highlighting the key determinants of commitment towards organizations and how do they influence employee behaviour and conduct at the workplace, yet such comprehensive studies in the local corporate context are limited. This is a pure quantitative research aimed at evaluating determinants of organizational commitment through survey. For this purpose, a questionnaire was designed and data was collected from a sample of 150 people within public and private sector organizations from banking industry. Nine hypotheses were developed and tested through Z-tests. Various other statistical techniques, including demographical analysis, reliability analysis and correlations were also employed for data analysis. The survey findings show strong correlations between various employee retention factors and the organizational commitment. The comparison of public and private sector in this regard reveals some interesting findings. The research concludes with various ways of devising strategies which can induce organizational commitment among employees and increase productivity.
\end{abstract}

Keywords: Organizational commitment, determinants, public and private sectors.

\section{Introduction}

\subsection{Background of Study}

Organizational commitment is a behavior that extends beyond the functions and conduct formally required of workers in an organization. Such behavior is indispensable because of its contribution to better organizational performance. Highly committed members are likely to be willing to contribute much effort on behalf of the organization. Strong commitment of an individual to an organization enables better adaptation capabilities and higher responsiveness to changes. In many organizations, the employee constitute major factor that influences the efficiency and professional functioning of the organizations. In order to adapt to environment constraints, the executives now a days try to promote certain behaviors and aspects among employees that ultimately stimulate commitment towards organization. Hence to function successfully, each organization is interested in exploiting factors that determine the organizational commitment of the employee.

Kamran Ahmed Malik is an MSMS student at SZABIST, Karachi.

Dr. Manzoor A. Khalidi is a faculty member at the National University of Computer \& Emerging Sciences, Karachi, manzoor.khalidi@nu.edu.pk

\begin{tabular}{llll|l}
\hline Journal of Independent Studies and Research - MSSE & Volume 10 & Number 1 & January 2012 & 61
\end{tabular} 
This research is conducted to analyze and evaluate the determinants of organizational commitment among employees. Various forms of organizational commitment and their constituents have been identified through literature for further analysis. A comparative analysis of various public and private sector organizations operating in Karachi is done in this regard. The research identifies specific forms and various determinants of organizational commitment in these organizations. It also presents the differences among the two sectors in terms of organizational commitment. The mechanisms for exploitation of organizational commitment determinants for enhanced outcome are also the integral part of this research. Although there have been numerous international studies on organizational commitment highlighting what are the key determinants of commitment towards organizations and how do they influence employee behaviour and conduct at the workplace, yet such comprehensive studies in the local corporate context are limited. This research aims to bring forth a comparison of public and private sector of Pakistan with a focus on organisations operating in Karachi. The research highlights and evaluates key determinants of organizational commitment in the local sector. Since no such study about comparison of public and private sectors is available specific to Pakistan, hence the findings of this research will help the public and private sector organizations operating in Pakistan to devise strategies which can induce organizational commitment among employees and increase the productivity. Furthermore, the research will bring forth comprehensive measures and recommendations regarding ways to enhance organizational commitment among professionals.

\subsection{Objective of Research}

The objective of this research is to understand:

- Specific types of organizational commitment

- Various determinants of organizational commitment

- Which determinants of organizational commitment are more effective

- The differences among public and private sector organizations in terms of organizational commitment

- Analysis and exploitation of various determinants of organizational commitment for enhanced outcomes

\subsection{Problem Statement}

The problem statement is as follows:

- What are the different types of organizational commitments prevailing in public and private sector and how various determinants affect organizational commitment?

\subsubsection{Research Methodology}

Determinants of organizational commitment have rarely been studied in the local context. This was a descriptive research with the employment of certain quantitative techniques. The research aimed to bring forth a comparison of public and private sectors in terms of organizational commitment and its determinants. The research was limited to the banking sector in Karachi.

\begin{tabular}{l|lll}
\hline 62 & January 2012 & Volume 10 Number $1 \quad$ Journal of Independent Studies and Research - MSSE
\end{tabular}




\subsection{Research Tools}

Two measuring instruments have been used in this research for the purpose of data collection. Organizational Commitment Questionnaire (OCQ) developed by Allen and Meyer (1990) was utilized for measuring the organizational commitment. OCQ consisted of a total of 18 items in which six items each measured Affective, Continuance and Normative commitment. In order to find out the determinants of organizational commitment, Retention Factors Measurement Scale (RFMS) developed by Dockels (2003) was used. RFMS consisted of a total of 35 items which were designed to measure compensation, career opportunities, training and development opportunities, supervisor support, work/life balance and job characteristics.

\subsubsection{Research Variables}

The determinants of organizational commitment are taken as independent variables for this research while three types of organizational commitment are taken as dependent variables. The independent variables (determinants) have been categorized as:

1. Compensation

2. Career Opportunities

3. Training \& Development opportunities

4. Supervisor support

5. Work-life balance

6. Job characteristics

As per the conceptual framework of the study, the types of organizational commitment are dependent on certain retention factors. These dependent variables have been classified as follows:

1. Affective commitment

2. Continuance commitment

3. Normative commitment

\subsubsection{Hypotheses}

Following are the hypotheses of this study:

$\mathrm{H} 1$ : The compensation system of the organization is satisfactory.

H2: There are significant career opportunities in the organization.

H3: There are significant training \& development opportunities in the organization.

$\mathrm{H} 4$ : There is adequate supervisor support in the organization.

H5: There is adequate work-life balance in the organization.

H6: Job characteristics are helpful in carrying out the routine tasks.

H7: There is adequate affective commitment in employees towards the organization.

$\mathrm{H} 8$ : There is adequate continuance commitment in employees towards the organization.

$\mathrm{H} 9$ : There is adequate normative commitment in employees towards the organization. 


\subsubsection{Respondents}

The respondents included middle management (i.e. managers, front-line managers, assistant managers, young executives and junior officers). Their bosses were mostly general managers, team/project leaders, assistant vice presidents etc. The sample included a total of 150 employees from public and private sectors. Data was collected from 75 employees of National Bank of Pakistan and 75 employees of Muslim Commercial Bank.

\subsubsection{Sampling}

Non probability sampling was designated for this research under which Convenience sampling was utilized.

\section{Organizational Commitment}

The concept of organizational commitment has received a lot of attention in recent years. With the passage of time and the advent of new technologies along with their application at workplace, the lives of individuals have received a considerable change. This has significantly affected the organizational commitment of employees all over the globe. The organizations have been facing tougher times due to the facts of turnover, absenteeism and reduced dedication. The organizational commitment has also been fluctuating regardless of the nature and type of organizations.

Allen and Meyer (1992) describe organizational commitment as the substance which keeps the individual attached with the organization. The construct of organizational commitment is different than the constructs of job satisfaction, workplace sanity and reduced turnover. Organizational commitment is something more deep and sacred than these other mentioned concepts. Highly committed members are likely to be willing to contribute much effort on behalf of the organization. Strong commitment of an individual to an organization enables better adaptation capabilities and higher responsiveness to changes (Armstrong \& Stassen, 1998). In many organizations, the employee constitute major factor that influences the efficiency and professional functioning of the organizations. In order to adapt to environment constraints, the executives now a days try to promote certain behaviors and aspects among employees that ultimately stimulates the commitment towards organization. Hence to function successfully, each organization is interested in exploiting factors that determine the organizational commitment of the employee.

Various researches have tried to describe some forms of organizational commitment and the critical determinants which have a positive and direct impact on organizational commitment. Different models and conceptual frameworks have been devised and tested with the prime objective of determining organizational commitment at the individual as well as the group level. In order to gauge the organizational commitment at different hierarchies, the multilevel analysis has also been performed. Literature suggests three different types of organizational commitments which have been made the focus of attention in this research.

\subsection{Affective Commitment}

Affective organizational commitment can be defined as the commitment of an individual towards the organization due to his/her emotional deviation towards that particular

64 January 2012 $\quad$ Volume $10 \quad$ Number $1 \quad$ Journal of Independent Studies and Research - MSSE


organization (Mowday, Steers, \& Porter, 1979). The organization in which the individual works is instrumental in guiding his/her life and decisions in many ways. The individual spend a considerable time of his life in the organization, hence s/he develops certain feelings towards that organization. These emotional feelings and attachment are the building blocks of organizational commitment. It is the affective commitment which keeps the employee attached with the organization even if there are hard times or some employee issues. Affective commitment is like owning the organization.

\subsection{Continuance Commitment}

Continuance organizational commitment can be defined as the willingness of an employee to continue rendering services to his organization by virtue of the consequences associated with leaving that organization (Porter \& Steers, 1973). This type of organizational commitment is most common in recent times. The employees remain committed to the organization due to the costs associated with leaving the organization. This includes the costs of withdrawing from the existing benefits received from the organization along with the costs of finding another job (Wiener, \& Gechman, 1977). Continuance commitment can be considered as the meagre form of organizational commitment. With the availability of certain attractive opportunities or career options, the employees having only continuance commitment are likely to switch their jobs. This is also the point of major concern for the organizations where only continuance commitment fosters. These organizations are likely to experience significant turnovers with the growth of market opportunities.

\subsection{Normative Commitment}

Normative organizational commitment can be defined as the obligation on the part of employee to serve the organization (Mottaz, 1988). This obligation can be classified as purely the moral obligation to render the services to the organization. Normative organizational commitment can be characterized as the most superior type of organizational commitment. The employees having this commitment are ready to give their maximum to the organization without even thinking of any materialistic benefits in reciprocation. Such elevated degree of organizational commitment can be considered as the supreme asset for the organization. Unfortunately, normative organizational commitment is currently the most preferred but least available form. The recent past has seen considerable degradation in the realm of organizational commitment with the most disastrous effect on the normative commitment. However, there exist certain organizations such as military organizations where normative organizational commitment is still prevailing. It is the dilemma of many organizations that they are not focusing attention on addressing the aspect of critical lower levels of normative commitment.

Researches have inferred that the construct total organizational commitment is the combination of all the three forms of organizational commitment i.e. affective commitment, continuance commitment and the normative commitment. The employees are perceived as in possession of some specific levels of all the three forms of organizational commitment (House, 1988). The researches have shown that the most common phenomenon is the combination of affective and considerable continuance commitment with only little degree of normative commitment. These combinations of organizational commitment in the employee keep on fluctuating with the age and stage of life cycle and external environment. However, this is certain that all three types of organizational commitment remain in the individual regardless of their level. 


\section{Determinants of Organizational Commitment}

Literature has identified various determinants of organizational commitment. Dockels (2003) proposed a six factor retention model which includes certain characteristics impacting the organizational commitment. The salient features of employee retention factor management are enumerated below. This is also called Retention Factor Measurement Scales (RFMS).

Compensation can be regarded as the most influential motivator for an individual to continue in an organization. As long as the compensation package is competitive, the employees continue to work with requisite zeal and zest. Studies have shown that compensation has the most profound impact on all types of organizational commitment. The presence of significant career opportunities also acts as a catalyst for the employee to give his/her optimum output to the organization. Career oriented practices such as internal promotions keep the employee attached with the organization. The organizations that religiously provide sufficient career progression opportunities to its employees are less likely to face the problems such as turnover and absenteeism.

Training and development instills a feeling of confidence and gratitude in the employees towards the organization. The organizations who invest heavily in their employees are able to retain them. The employees in turn also develop an obligation to stay and serve the organization. Supervisor support refers to the behaviors that help the employees to perform their routine tasks effectively. Valuable feedbacks, praise and recognition of work by supervisor fosters the commitment level of an employee towards the organization. This not only binds the employee with the organization but also create a harmony and sanity at the workplace.

In the recent past, the human resource professionals have been increasingly emphasizing on this aspect which has largely remained ignored previously. With the advent of modern technologies and increased innovations at workplace, the routine life of an individual has experienced a phenomenal acceleration. Furthermore, the global recession hitting the economies worldwide has converted the careers of employees into a never ending race for survival. Job characteristics also play a pivotal role in ensuring workplace sanity and satisfaction among employees. The organizations with formalized work settings and efficient systems are likely to retain the employees. The individuals who experience sufficient freedom and autonomy also tend to reciprocate this factor in their work and organizational outputs.

\section{Analysis / Results}

\subsection{Demographical Analysis}

\section{GENDER}

\begin{tabular}{|cl|c|c|c|c|}
\hline & & Frequency & Per cent & Valid Per cent & Cumulative Per cent \\
\hline Valid & Male & 122 & 81.3 & 81.3 & 81.3 \\
& Female & 28 & 18.7 & 18.7 & 100.0 \\
& Total & 150 & 100.0 & 100.0 & \\
\hline
\end{tabular}

\begin{tabular}{l|lll}
\hline 66 & January 2012 & Volume 10 & Number $1 \quad$ Journal of Independent Studies and Research - MSSE
\end{tabular}


AGE

\begin{tabular}{|ll|c|c|c|c|}
\hline & & Frequency & Per cent & Valid Per cent & Cumulative Per cent \\
\hline Valid & $20-25$ & 26 & 17.8 & 17.8 & 17.8 \\
& $26-30$ & 80 & 53.1 & 53.1 & 70.9 \\
& $31-35$ & 38 & 25.0 & 25.0 & 95.9 \\
& 36 and above & 6 & 4.1 & 4.1 & 100.0 \\
& Total & 150 & 100.0 & 100.0 & \\
Missing & 0 & 0 & 0 & & \\
Total & 150 & 100.0 & & & \\
\hline
\end{tabular}

QUALIFICATION

\begin{tabular}{|ll|c|c|c|c|}
\hline & & Frequency & Per cent & Valid Per cent & Cumulative Per cent \\
\hline Valid & Bachelors & 35 & 22.9 & 22.9 & 22.9 \\
& Masters & 96 & 63.5 & 63.5 & 86.4 \\
& Post Graduate & 15 & 10.4 & 10.4 & 96.8 \\
& Other & 4 & 3.1 & 3.1 & 100.0 \\
Total 150 & 100.0 & 100.0 & & \\
\hline
\end{tabular}

\subsection{Hypothesis Testing}

$\mathrm{HO}$ : The compensation system of the organization is satisfactory.

$\mathrm{Ha}$ : The compensation system of the organization is not satisfactory.

\section{PUBLIC SECTOR}

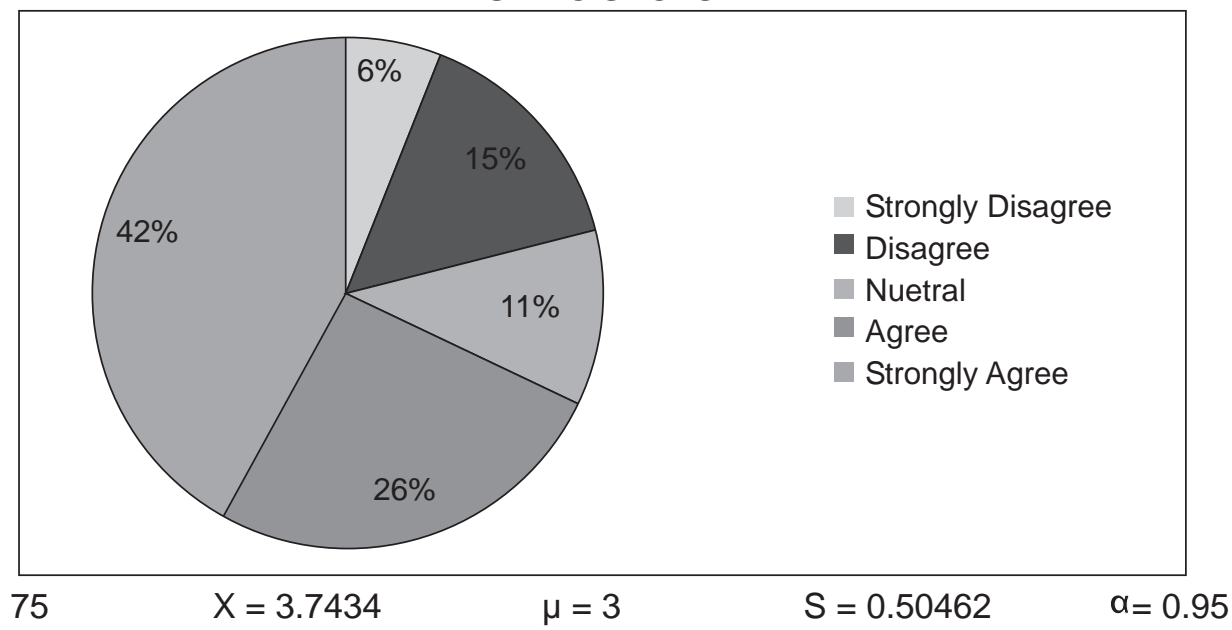

Using Z-test,

Result: $\mathrm{H} 0$ is accepted. 


\section{PUBLIC SECTOR}

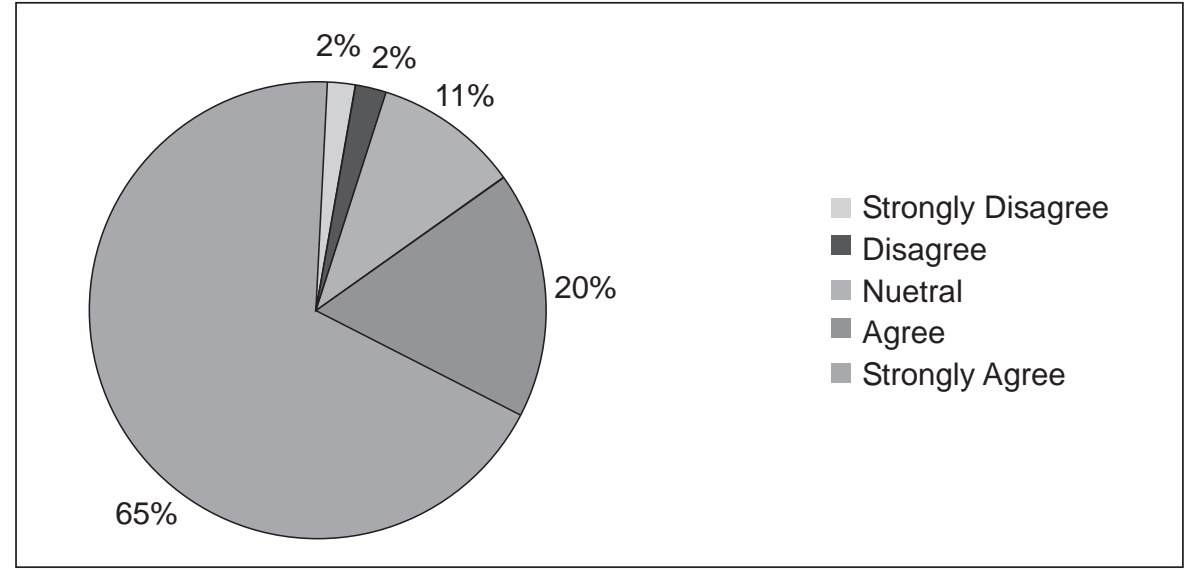

$N=75$

$X=4.3334$

$\mu=3$

$S=0.54716$

$\alpha=0.95$

Using Z-test,

Result: $\mathrm{HO}$ is accepted.

$\mathrm{HO}$ : There are significant career opportunities in the organization $\mathrm{Ha}$ : There are no significant career opportunities in the organization.

PUBLIC SECTOR

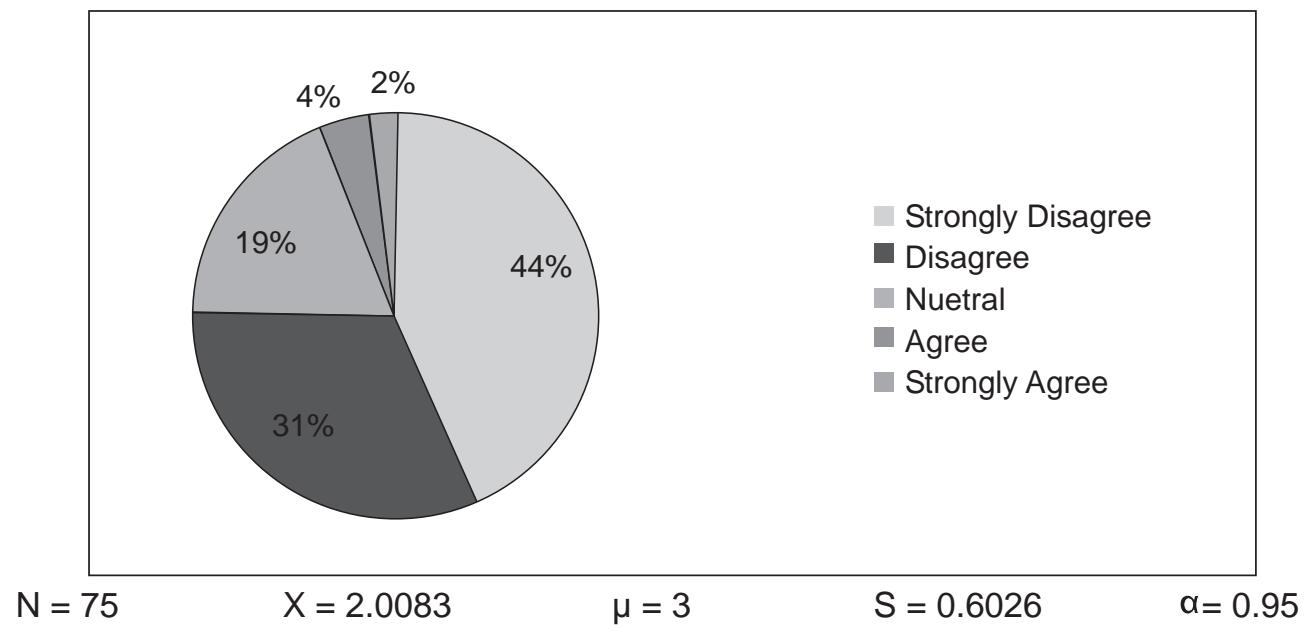

Using Z-test,

Result: $\mathrm{HO}$ is rejected.

68 January 2012 $\quad$ Volume $10 \quad$ Number $1 \quad$ Journal of Independent Studies and Research - MSSE 


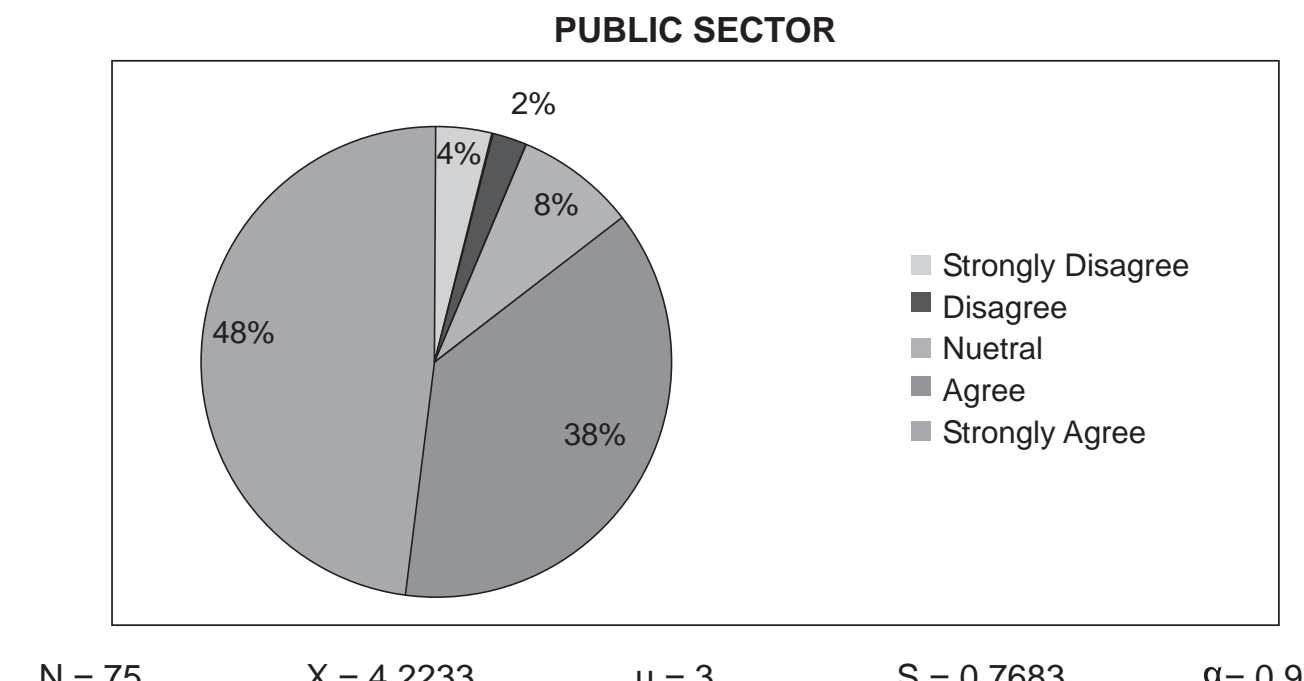

$N=75$

$X=4.2233$

$\mu=3$

$S=0.7683$

$a=0.95$

Using Z-test,

Result: $\mathrm{HO}$ is accepted.

HO: There are significant training \& development opportunities in the organization. Ha: There are no significant training \& development opportunities in the organization.

PUBLIC SECTOR

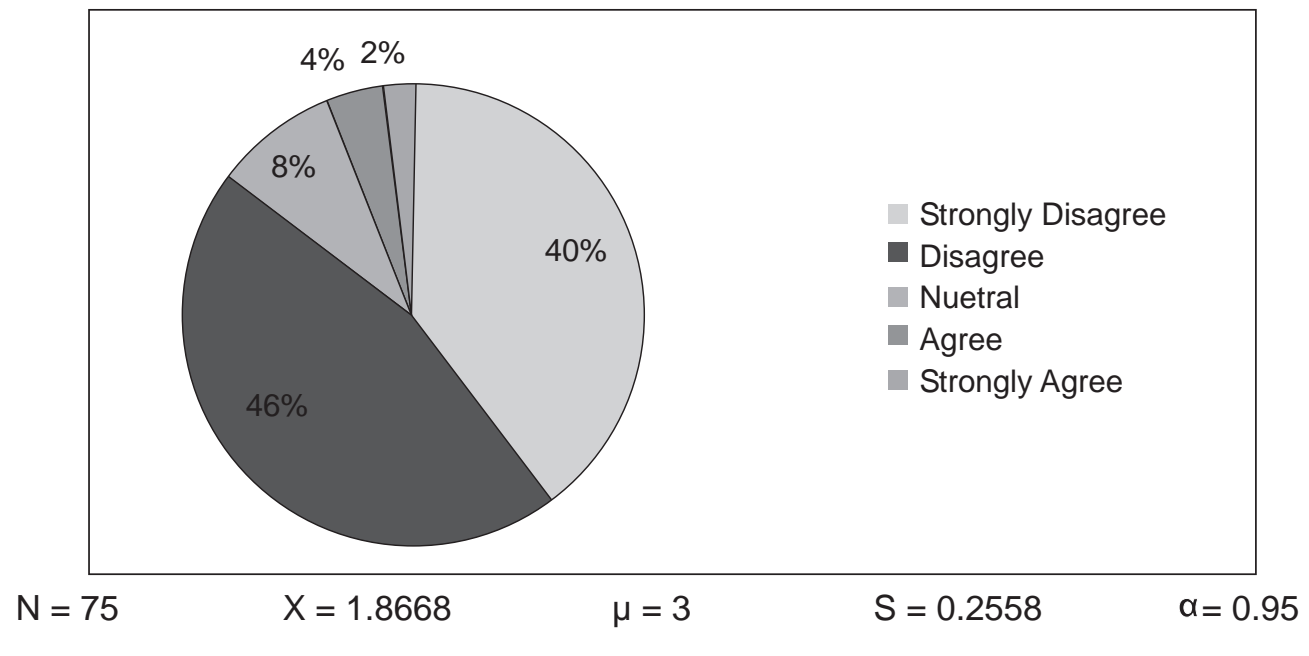

Using Z-test,

Result: $\mathrm{HO}$ is rejected. 


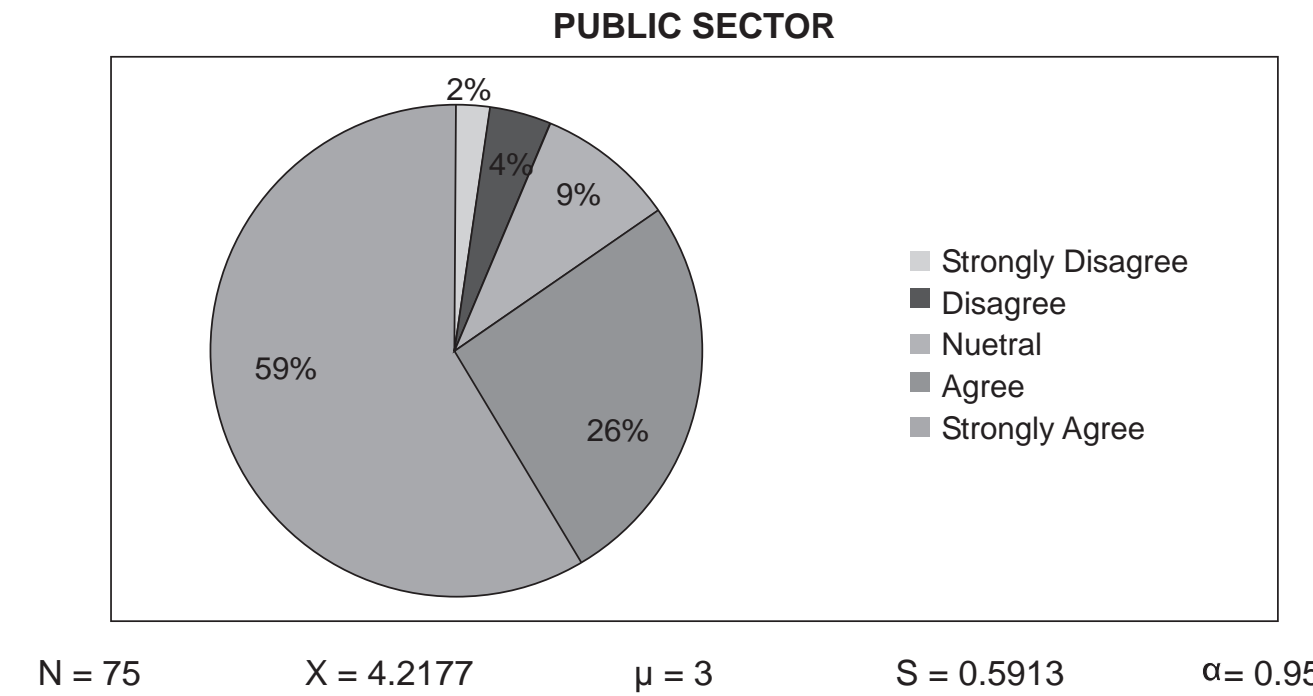

Using Z-test,

Result: $\mathrm{HO}$ is accepted.

$\mathrm{HO}$ : There is adequate supervisor support in the organization.

Ha: There is no adequate supervisor support in the organization.

PUBLIC SECTOR

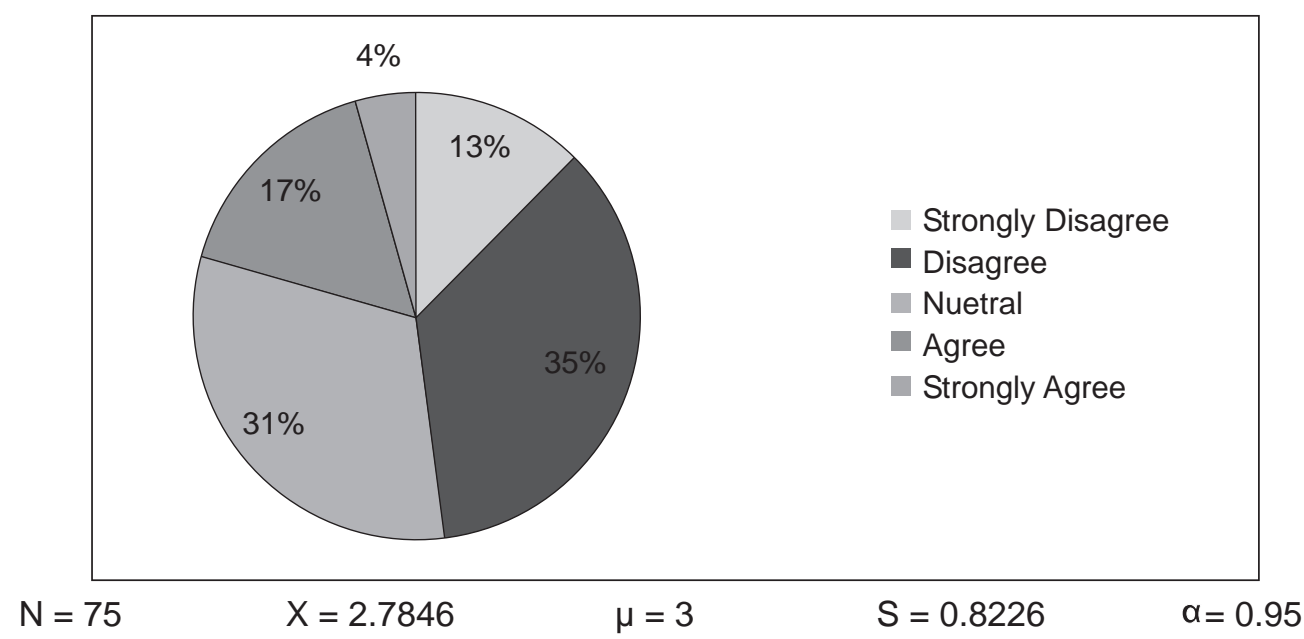

Using Z-test, Result: $\mathrm{H} 0$ is rejected.

\begin{tabular}{l|lll}
\hline 70 & January 2012 & Volume 10 & Number $1 \quad$ Journal of Independent Studies and Research - MSSE
\end{tabular} 


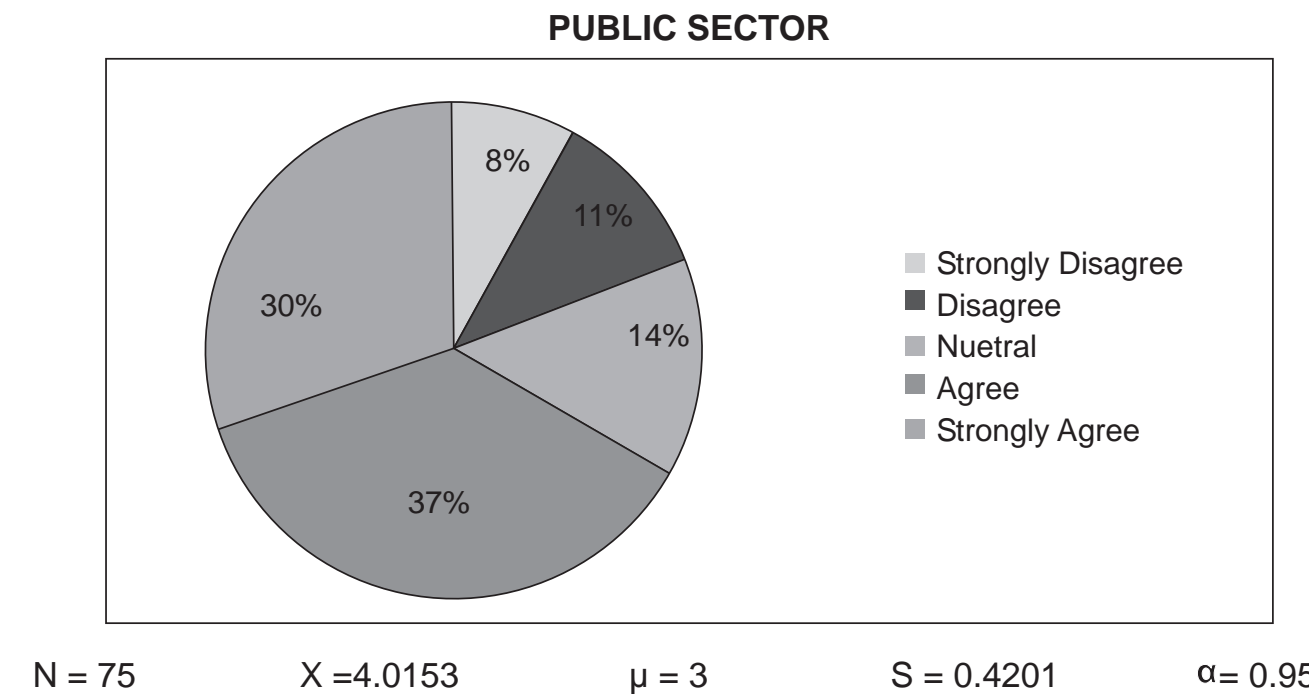

Using Z-test,

Result: $\mathrm{HO}$ is accepted.

$\mathrm{HO}$ : There is adequate work-life balance in the organization.

$\mathrm{Ha}$ : There is no adequate work-life balance in the organization.

PUBLIC SECTOR

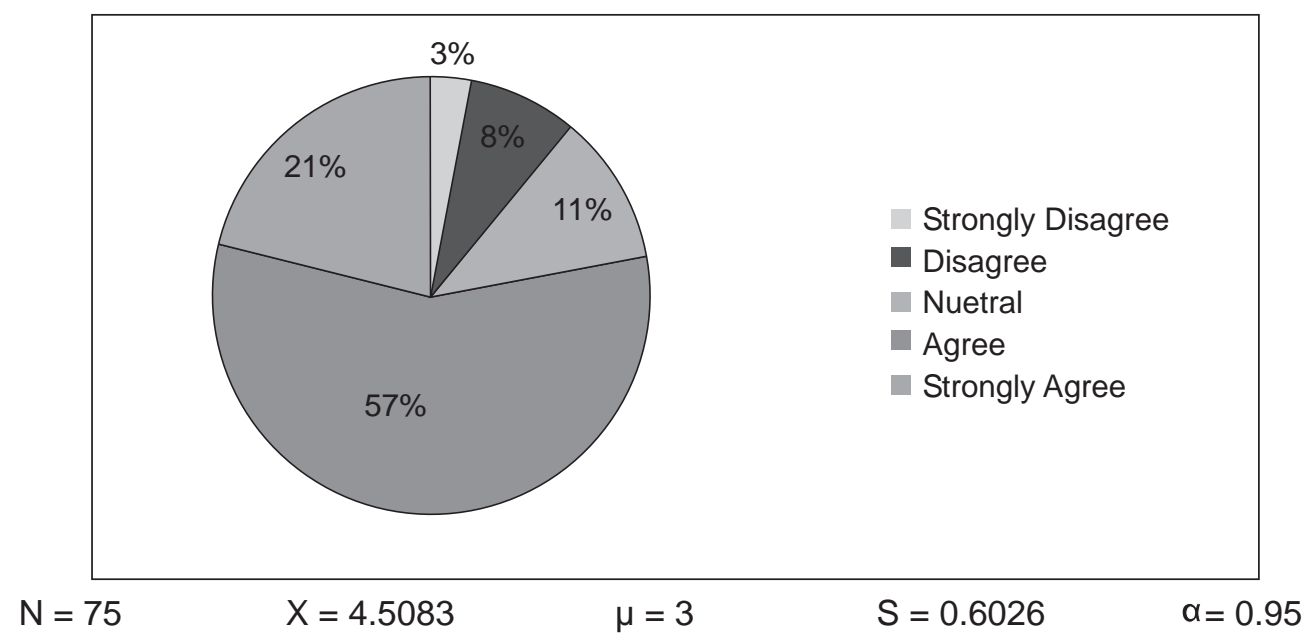

Using Z-test, Result: $\mathrm{HO}$ is accepted. 
PUBLIC SECTOR

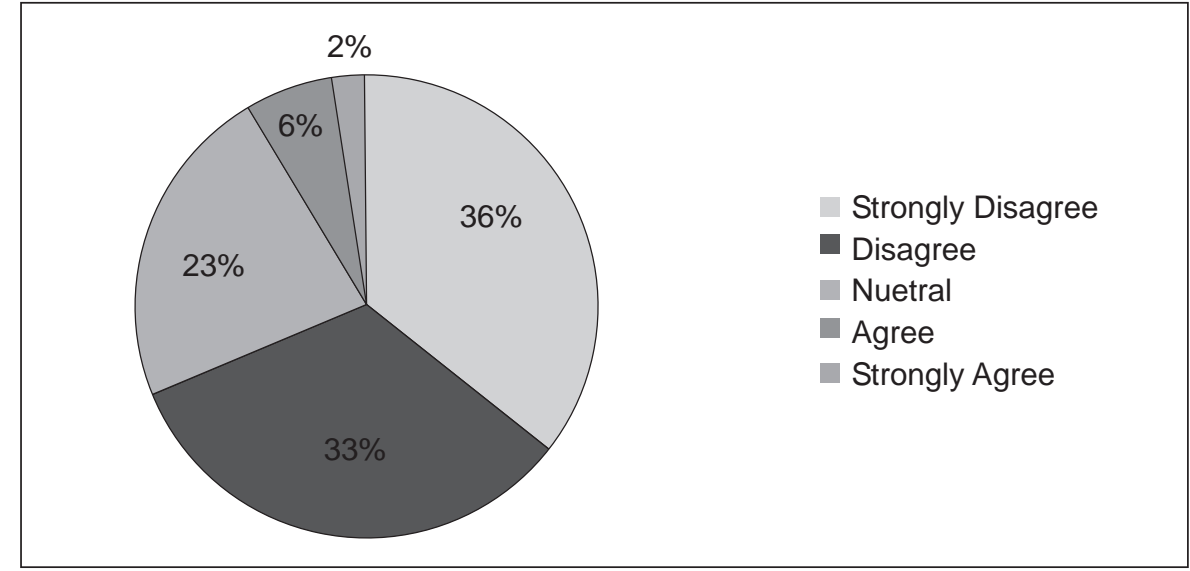

$N=75$

$X=2.1434$

$\mu=3$

$S=0.50462$

$a=0.95$

Using Z-test,

Result: $\mathrm{HO}$ is rejected.

$\mathrm{HO}$ : Job characteristics are helpful in carrying out the routine tasks.

$\mathrm{Ha}$ : Job characteristics are not helpful in carrying out the routine tasks.

PUBLIC SECTOR

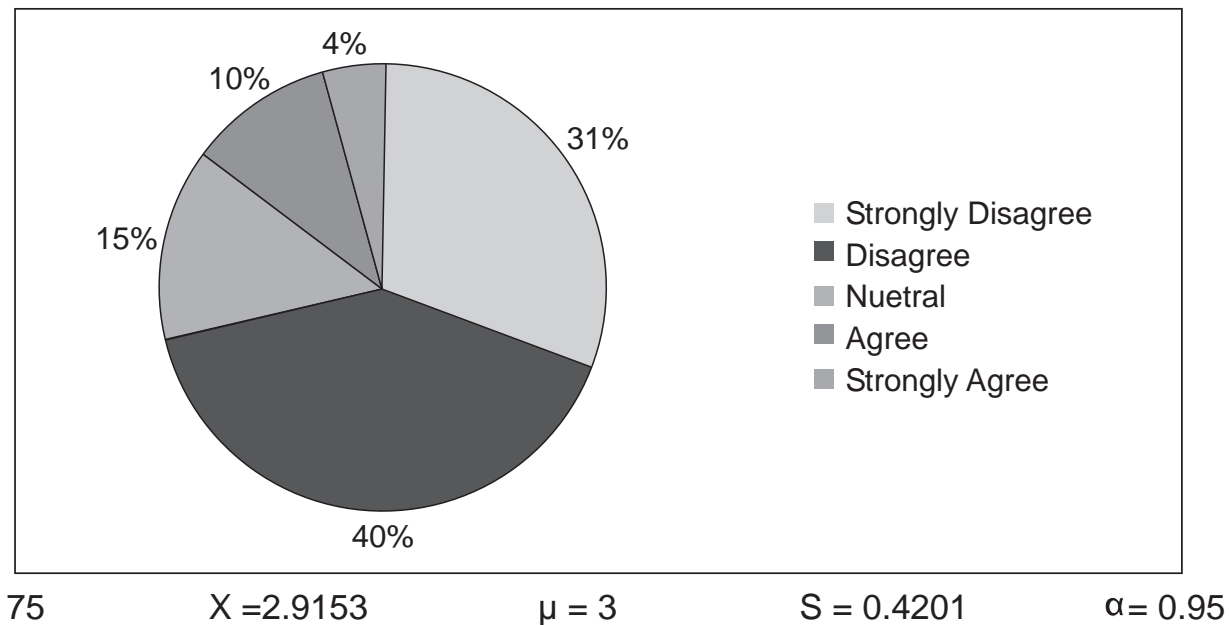

Using Z-test, Result: $\mathrm{HO}$ is rejected.

\begin{tabular}{l|lll}
\hline 72 & January 2012 & Volume 10 & Number $1 \quad$ Journal of Independent Studies and Research - MSSE
\end{tabular} 


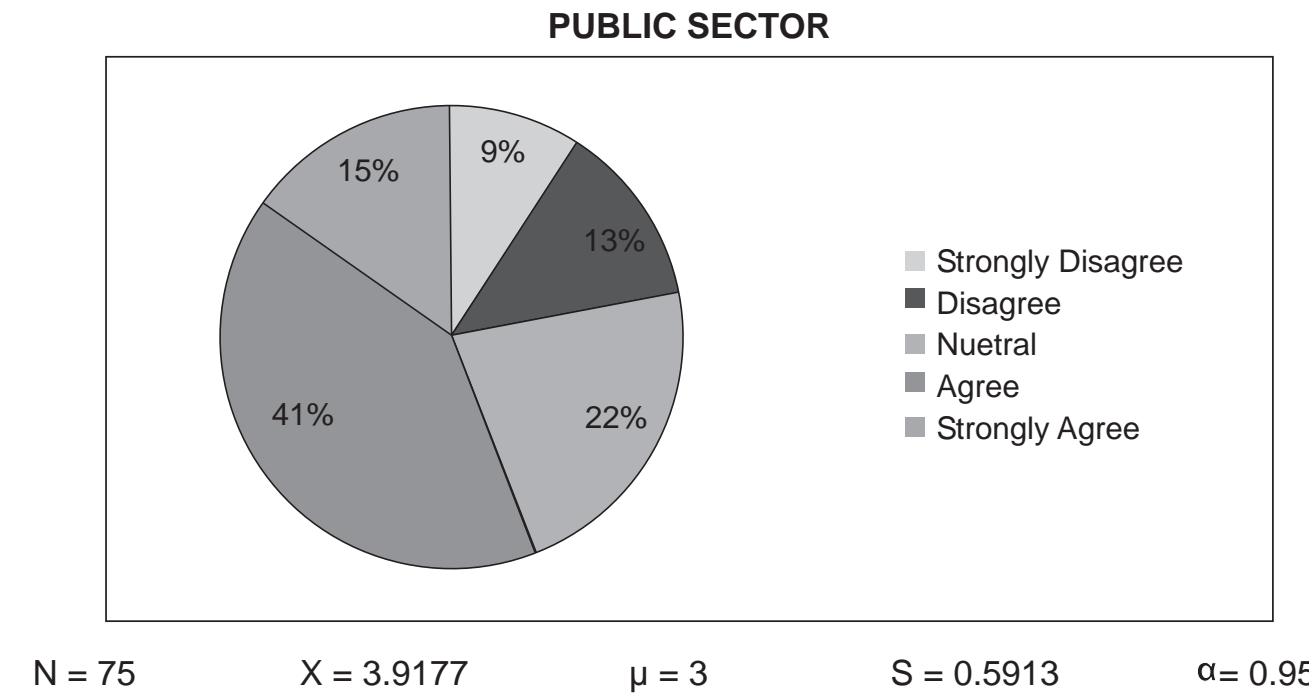

Using Z-test,

Result: $\mathrm{HO}$ is accepted.

$\mathrm{HO}$ : There is adequate affective commitment in employees towards the organization. $\mathrm{Ha}$ : There is no adequate affective commitment in employees towards the organization.

PUBLIC SECTOR

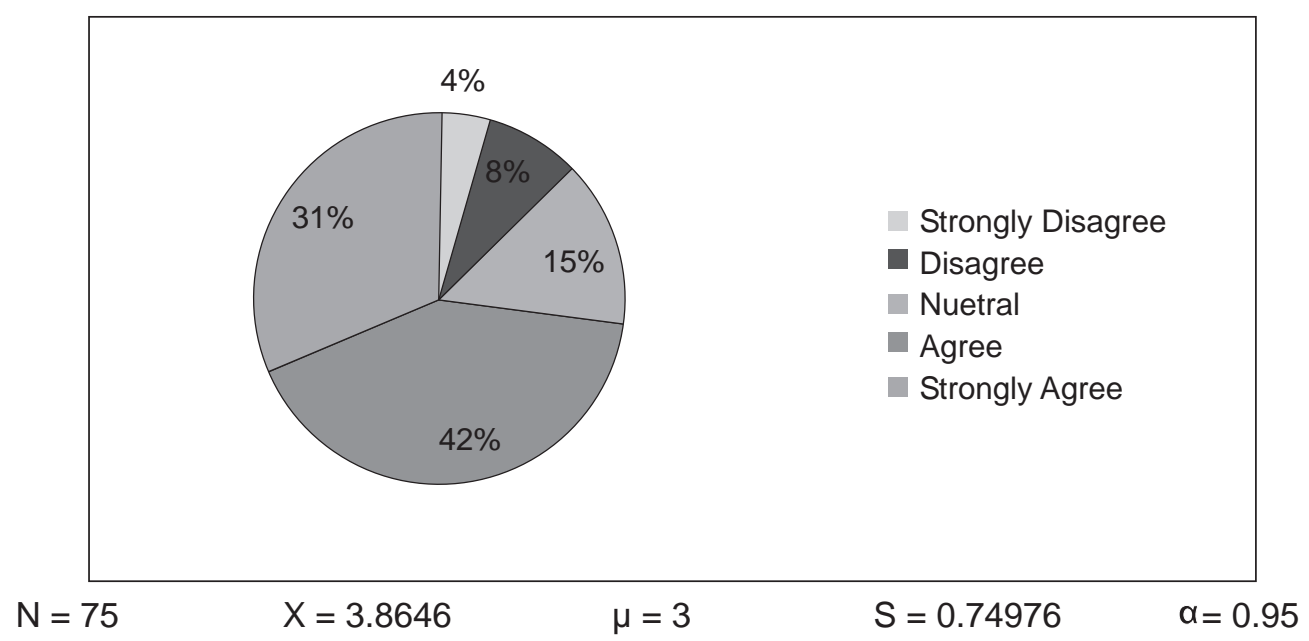

Using Z-test, Result: $\mathrm{HO}$ is accepted. 


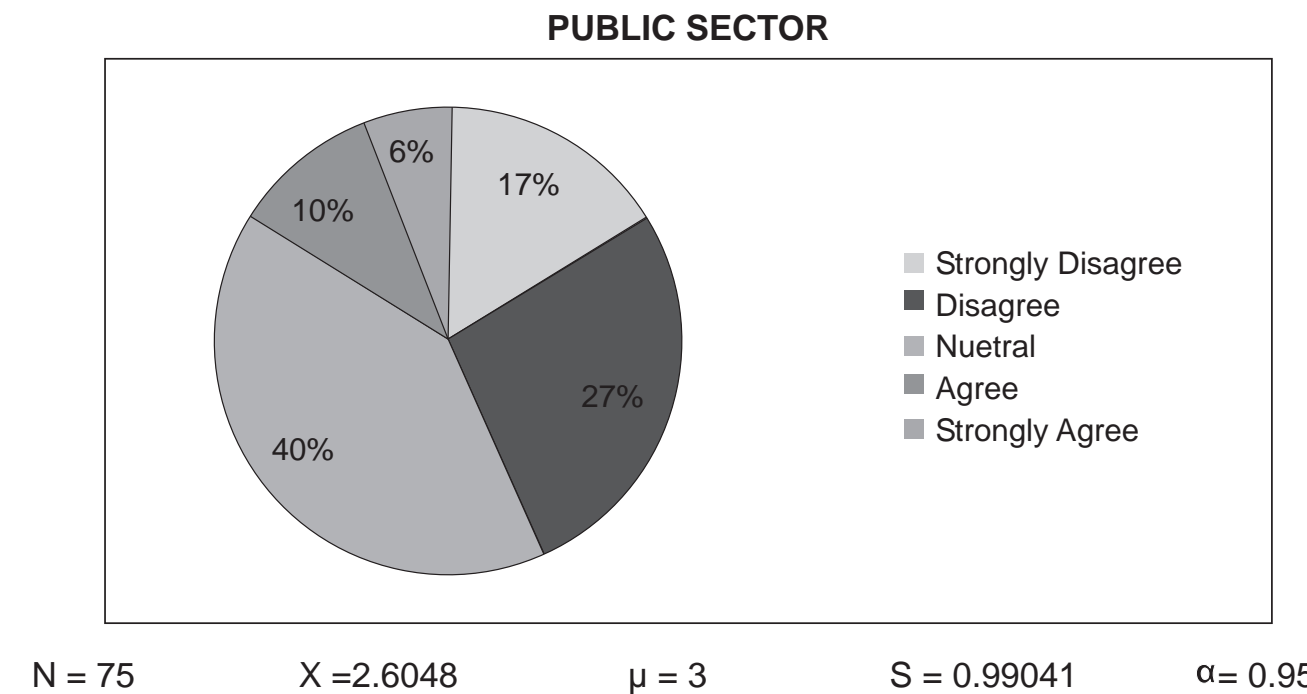

Using Z-test,

Result: $\mathrm{HO}$ is rejected.

$\mathrm{HO}$ : There is adequate continuance commitment in employees towards organization. Ha: There is no adequate continuance commitment in employees towards organization.

PUBLIC SECTOR

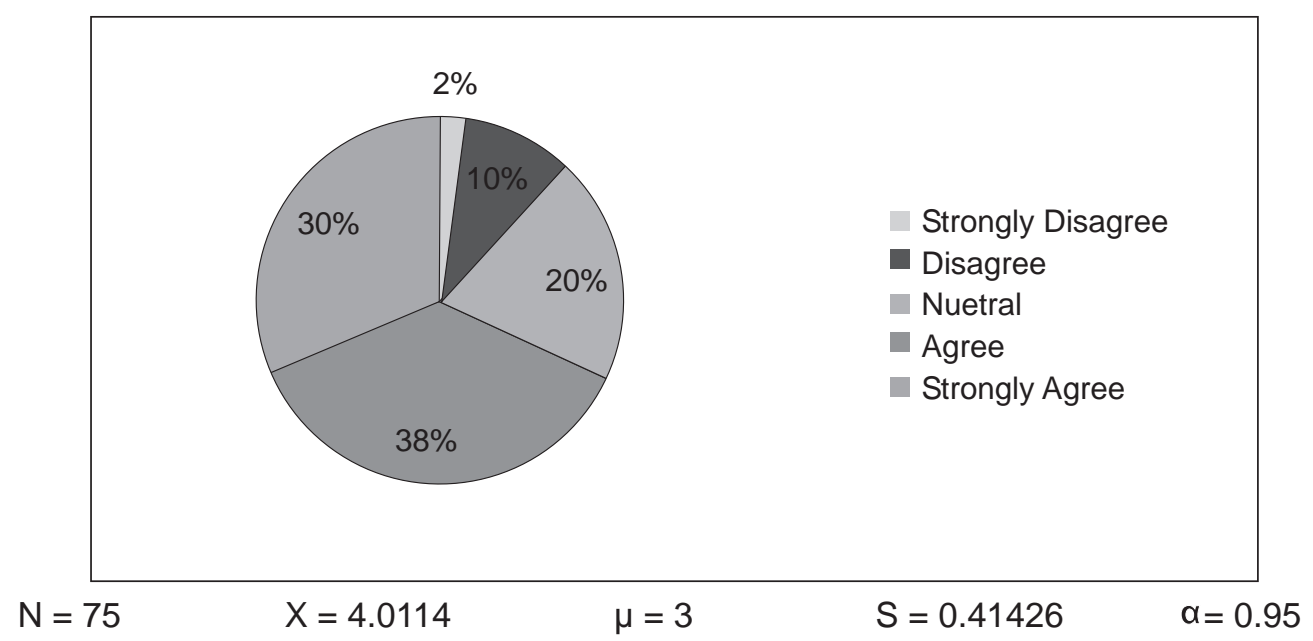

Using Z-test, Result: $\mathrm{HO}$ is accepted.

\begin{tabular}{l|lll}
\hline 74 & January 2012 & Volume 10 & Number $1 \quad$ Journal of Independent Studies and Research - MSSE
\end{tabular} 


\section{PUBLIC SECTOR}

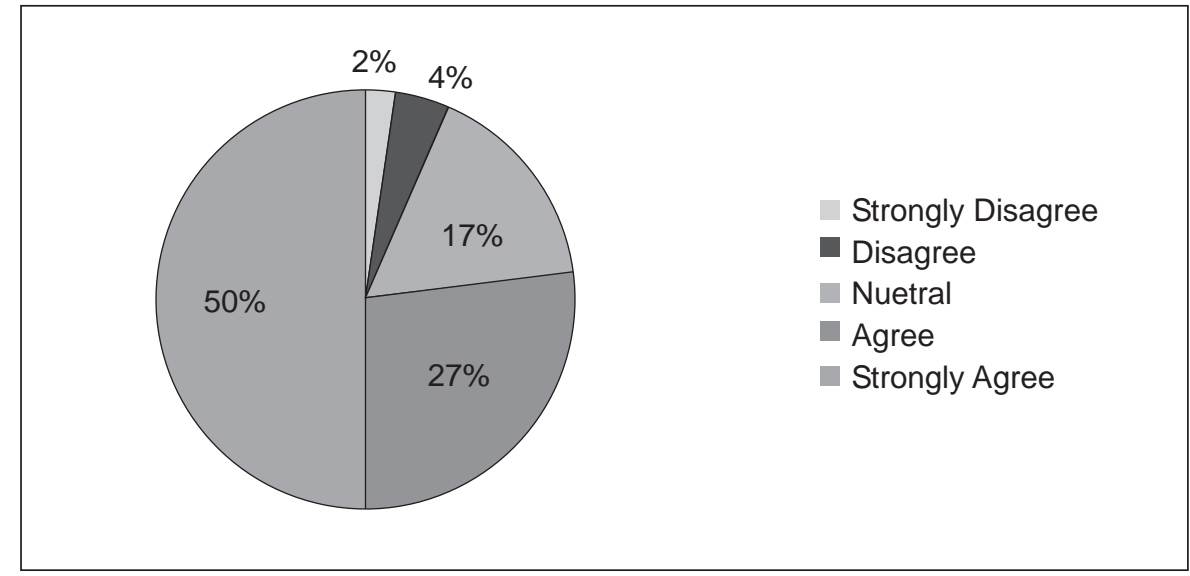

$\mathrm{N}=75$

$X=4.1999$

$\mu=3$

$S=0.61237$

$\alpha=0.95$

Using Z-test,

Result: $\mathrm{HO}$ is accepted.

$\mathrm{HO}$ : There is adequate normative commitment in employees towards the organization. $\mathrm{Ha}$ : There is no adequate normative commitment in employees towards the organization.

\section{PUBLIC SECTOR}

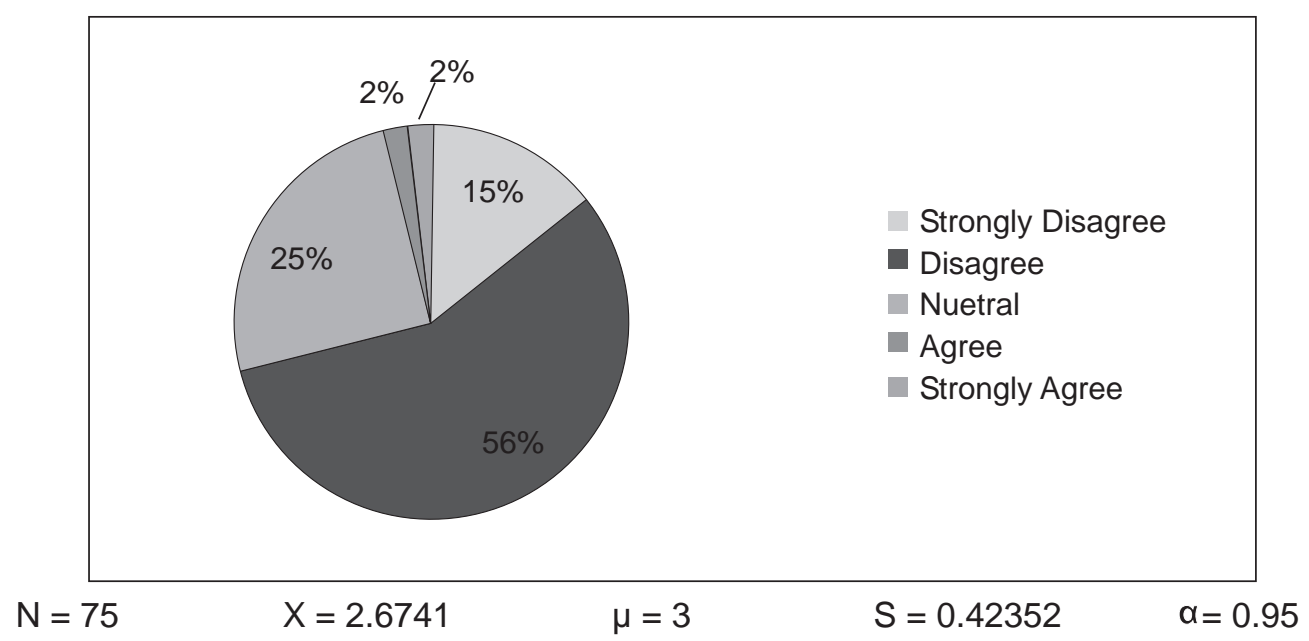

Using Z-test,

Result: $\mathrm{HO}$ is rejected. 


\section{PUBLIC SECTOR}

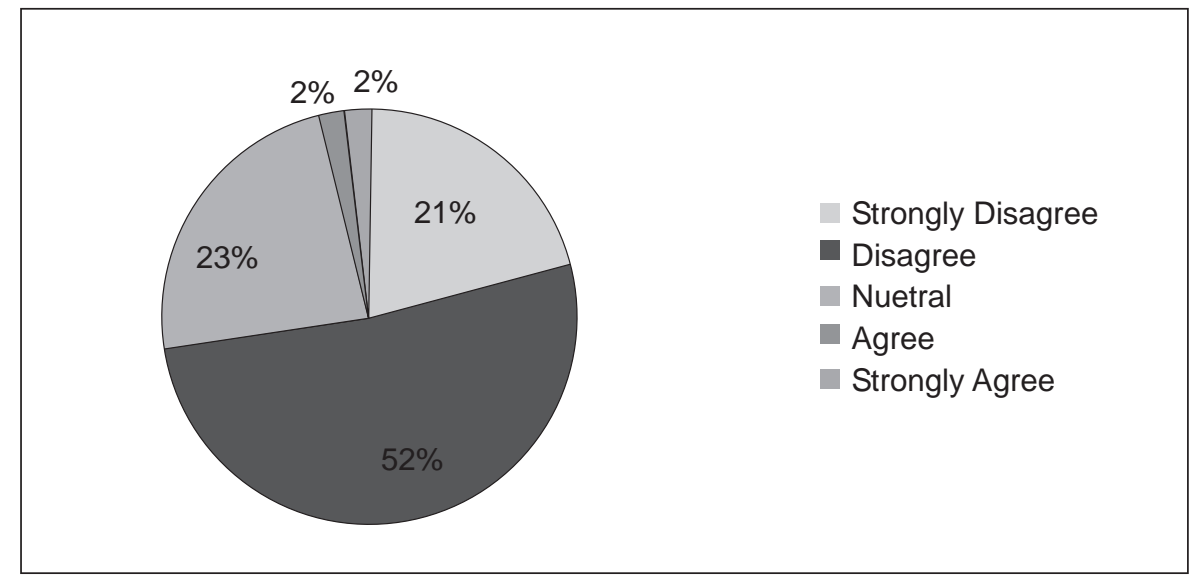

$\mathrm{N}=75$

$X=2.1457$

$\mu=3$

$S=0.49124$

$\alpha=0.95$

Using Z-test,

Result: $\mathrm{HO}$ is rejected.

\section{Discussion}

This study tried to evaluate different determinants of various types of organizational commitments prevailing in public and private sector organizations in Pakistan. The first hypothesis of this study is that the compensation system of the organization is satisfactory. Compensation can be regarded as the most influential motivator for an individual to continue in an organization. As long as the compensation package is competitive, the employees continue to work with requisite zeal and zest. The findings of this study show that both public and private sector employees are satisfied with their compensation. The respondents from both categories termed their overall package as fair, competitive and market based. Both segments were satisfied with their respective pay levels, increments and overall financial package. Hence the hypothesis was accepted in case of both public and private sectors.

The second hypothesis of this study is that there are significant career opportunities in the organization. The presence of significant career opportunities acts as a catalyst for the employee to give his/her optimum output to the organization. Career oriented practices such as internal promotions keep the employee attached with the organization. The organizations that religiously provide sufficient career progression opportunities to its employees are less likely to face the problems such as turnover and absenteeism. The results of this study show that there is a difference in the perceptions of public and private sector employees with regard to the career opportunities. The private sector employees were found to be satisfied with the career opportunities available to them. Performance based growth emerged as a prime factor of their satisfaction with career opportunities. On the other hand, the public sector employees were found to be dissatisfied with their career opportunities. Political influence was attributed as the main factor behind this dissatisfaction. 
The third hypothesis of this study is that there are significant training and development opportunities in the organization. Training and development instill a feeling of confidence and gratitude in the employees toward the organization. The organizations that invest heavily in their employees are able to retain them. The employees in turn also develop an obligation to stay and serve the organization. When this hypothesis was tested upon public and private sector respondents of this study, significant differences were observed. The private sector employees were found to be contended with their training and development opportunities. The main factors were: a formalized training policy, training need analysis and sponsored training programs both inland and abroad. Contrary to this, public sector employees regarded their training and development opportunities as insufficient and insignificant, mainly due to the absence of a comprehensive training mechanism.

The fourth hypothesis of this study is that there is adequate supervisor support in the organization. Supervisor support refers to the behaviors that help the employees to perform their routine tasks effectively. Valuable feedbacks, praise and recognition of work by supervisor(s) foster the commitment level of an employee towards the organization. This not only binds the employee with the organization but also create harmony and sanity at the workplace. When this aspect was analyzed with regard to public and private sector organizations, strong deviations in terms of responses were observed. The private sector employees were found to be satisfied with the supervisor support which they experience at workplace. Managerial interest in employee affairs and significant facilitation of work were the prime aspects highlighted by the private sector employees. On the other hand, the public sector employees did not declare their supervisor as supportive/ facilitator. The factor attributable to this effect is the structure/functioning of public sector institutions where performance and productivity issues are not addressed efficiently. The political appointments are also a factor of declining managerial interest in employees' issues or support for their concerns.

The fifth hypothesis of this study is that there is adequate work-life balance in the organization. In the recent past, the human resource professionals have been increasingly emphasizing on this aspect which has largely remained ignored previously. With the advent of modern technologies and increased innovations at workplace, the routine life of an individual has experienced a phenomenal acceleration. Furthermore, the global recession hitting the economies worldwide has converted the careers of employees into a never ending race for survival. When this hypothesis was tested in this study, the findings emerged were quite obvious and expected. The private sector employees were found to be extremely dissatisfied with their work-life balance. Late sittings, inadequate leaves/holidays and lack of available substitutes were the contributing factors toward this dissatisfaction. However, the situation was completely opposite in case of public sector employees who were found to be extremely satisfied with their work-life balance. The prime factor was the availability of sufficient human resource to cater for any type of workload and ensure redundancy.

The sixth hypothesis of this study is that job characteristics are helpful in carrying out the routine task. Job characteristics play a pivotal role in ensuring workplace sanity and satisfaction among employees. The organizations with formalized work settings and efficient systems are likely to retain the employees. The individuals who experience sufficient freedom and autonomy also tend to reciprocate this factor in their work. 
The analysis of public and private sectors in this aspect brings forth different results. The private sector employees were found to be satisfied with their job characteristics. The factors attributed to this were sufficient autonomy, feedback mechanisms, efficient systems and human resource management softwares. Contrary to this, the public sector employees did not enjoy helpful job characteristics as per their responses. They termed their jobs as less autonomous and innovative. This is further aggravated due to non availability of adequate IT support and HR softwares in public sector institutions.

The last three hypothesis of this study are about existence of affective, continuance and normative types of organizational commitment in public and private sectors. An analysis of both the segments reveals that there exists sufficient affective and continuance commitment in the employees of public sector. However, the private sector employees were found to have only continuance organizational commitment.

The analyses of first six and last three hypothesis of this study provide some interesting insights into the realm of organizational commitment. The private sector employees were found to be content with all the retention factors except work-life balance. Yet they possessed only one form of organizational commitment i.e. continuance commitment, which is the intention to stay in the organization mainly due to lack of significant alternatives. The other commitments i.e. Affective (emotional attachment with organization) and Normative (obligation to serve the organization) were found missing. On the other hand, the public sector employees were found to be dissatisfied with all the retention factors except compensation and work-life balance. Despite this dissatisfaction with majority of retention factors, significant existence of Affective commitment (emotional attachment with organization) and Continuance commitment (willingness to stay due to lack of alternatives) was observed in public sector employees.

Considering the compensation related satisfaction common to both the segments of respondents, work-life balance has emerged as the prime differentiating and deciding factor in terms of organizational commitment of public and private sectors' employees. With the passage of time, more families are resorting to dual working in order to cater for increasing expenses. This has greatly necessitated the existence of a work-life balance in the routines of employees. The organizations catering for this factor are more likely to induce higher levels of all forms of organizational commitment into its employees.

\section{Conclusion}

Organizational commitment is a phenomenon different from other constructs such as job satisfaction and reduced turnover. It is a psychological state that keeps the individuals embedded with the organization. The three forms of organizational commitment (i.e. affective, continuance and normative) are instrumental in evaluating the precise determinant of organizational commitment. The comparison of public and private sectors in this regard has revealed higher levels of organizational commitment in the public sector. However, the most important form of organizational commitment i.e. Normative commitment, which is the obligation to serve the organization, has been found missing in both public and private sector.

\begin{tabular}{l|lll}
\hline 78 & January 2012 & Volume 10 & Number $1 \quad$ Journal of Independent Studies and Research - MSSE
\end{tabular}


Work-life balance has emerged as the most significant determinant of organizational commitment. This study shows that the entire positive attributes of private sector i.e. good compensation, career opportunities, training \& development opportunities, supervisor support and helpful job characteristics are neutralized due to absence of work-life balance. On the other hand, the public sector institutions by virtue of their structure and functioning have somehow been able to provide significant work-life balance to their employees. This provision of work-life balance in public sector results in the absence of other retention factors/determinants of organizational commitment. Hence it is concluded that work-life balance is the major determinant of organizational commitment which has been found in public sector but not in private sector. 


\section{References}

Allen, N. J. \& Meyer, J. P. 1990, 'The measurement and antecedents of affective, continuance, and normative commitment,' Journal of Occupational Psychology, Vol. 63, pp. 1-18.

Armstrong-Stassen, M., 1998, 'Downsizing the federal government: A longitudinal study of managers' reactions', Canadian journal of Administrative Sciences, Vol. 15, No. 4, pp. 310-321

Brockner, J., Tyler, T. R. and Cooper-Schneider, Rochelle, 1992, 'The influence of prior commitment to an institution on reactions to perceived unfairness: The higher they are, the harder they fall', Administrative Science Quarterly, Vol. 47, pp. 241-261.

Brockner, J., Grover, S. L., \& Blonder, M. D. 1988, 'Predictors of survivors' job involvement following layoffs: A field study,' Journal of Applied Psychology, Vol. 73, pp. 436-442.

Buchanan, B. II, 1974, 'Building organizational commitment: The socialization of managers in work organizations', Administrative Science Quarterly, Vol. 22, pp. 533-546.

Hall, D. T., Schneider B. \& Nygren, H. T. 1970, 'Personal factors in organizational identification,' Administrative Science Quarterly, Vol. 15, pp. 176-190.

House, R. J. 1988, 'Power and personality in complex organizations,' in Cummings, L. L. \& Staw, B. M. (ed.), Research in Organizational Behavior, Vol. 10, pp. 305-357.

Iverson, R. D. 1996, 'Employee acceptance of organizational change: the role of organizational commitment,' International Journal of Human Resource Management, Vol. 7, No. 1, pp. 121-148.

Meyer, John P., Allen, Natalie J. \& Smith, Catherine A. 1993, 'Commitment to organizations and occupations: Extension and test of a three-component conceptualization,' Journal of Applied Psychology, Vol. 78, No. 4, pp. 538-551.

Meyer, J. P. \& Allen, N. J. 1991, 'A three-component conceptualization of organizational commitment,' Human Resource Management Review, Vol. 1, pp. 61-98.

Meyer, J. P., Paunonen, S., Gallatly V., Goffin, I. R. \& Jackson, D. N. 1989, 'Organizational commitment and job performance: It is the nature of the commitment that counts,' Journal of Applied Psychology, Vol. 74, No. 1, pp. 152-156.

Meyer, John, P. \& Allen, N.J., 1984, 'Testing the Side-Bet Theory of organizational commitment: Some Methodological considerations,' Journal of Applied Psychology, Vol. 69, No. 3, pp. 372-378.

Mottaz, C.J., 1988, 'Determinants of organizational commitment', Human Relations, Vol. 41, pp. 467-482

Mowday, R., Steers, R. \& Porter, L. W., 1979, 'The measurement of organizational commitment,' Journal of Vocational Behavior, Vol. 14, pp. 224-247.

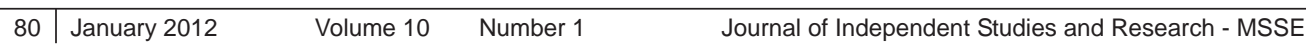


Mowday, R., Steers, R. \& Porter, L. W., 1982, 'Organizational linkages: The psychology of commitment, absenteeism, and turnover,' San Diego, CA: Academic Press.

O'Reily, C. A. \& Chatman, J. 1986, 'Organizational commitment and psychological attachment: The effects of compliance, identification and internalization on prosocial behavior,' Journal of Applied Psychology, Vol. 71, pp. 361-378

Oldham, G. R. 1976, 'The motivational strategies used by supervisors relationships to effectiveness indicators,' Organizational Behavior and Human performance, Vol. 16, pp. 66-86.

Porter, L. W., Crampton, W. J. and Smith, F. W. 1976, 'Organizational commitment and managerial turnover: Longitudinal study,' Organizational Behavior and Human Performance, Vol. 15, pp. 87-98

Porter, L. W. \& Steers, R. M. 1973, 'Organizational, work and personal factors in employee turnover and absenteeism,' Psychological Bulletin, Vol. 80, pp. 151-176.

Porter, L. W., \& Steers, R. M., Mowday, R. T., \& Boulian, P. V. 1974, 'Organizational commitment, job satisfaction ad turnover among psychiatric technicians,' Journal of Applied Psychology, Vol. 59, pp. 603-609.

Steers, R. M.1977, 'Antecedents and outcomes of organizational commitment,' Administrative Science Quarterly, Vol. 22, pp. 46-56.

Wiener, Y.1982, 'Commitment in organizations: A normative view,' Academy of Management Review, Vol. 7, No. 3, pp. 418-428.

Wiener, Y., \& Gechman, A. G. 1977, 'Commitment: A behavioral approach to job involvement,' Journal of Vocational Behavior, Vol. 10, pp. 47-52. 